\title{
거래회전율이 높은 단지는 가격이 비싼가? : 확정일자 신고자료를 활용한 전세가격 분석 \\ 정화미 ${ }^{*}$ 이용만**
}

우리나라 주택시장에는 거래가 활발하면 가격도 비싸다는 믿음이 있다. 우리는 이 믿 음이 서울 강남구와 노원구 아파트 전세 시장에서도 사실인지를 실제 전세거래자료를 활용하여 분석하였다. 분석 모형은 헤도닉 가격 모형을 사용하였고 전세거래 자료는 2018년 아파트 확정일자 자료를 활용하였다.

분석 결과 단지별 전세거래 회전율 증감은 지역에 따라 전세가격에 미치는 영향이 다 르게 나타났다. 강남구에서는 전세거래 회전율이 큰 단지일수록 전세가격이 낮았고, 노원구에서는 회전율이 큰 단지일수록 전세가격이 높았다. 이는 두 지역의 전세시장 구조가 다르기 때문인 것으로 판단된다.

따라서 전세거래회전율이 높다고 전세가격이 비싸다고 시장을 해석하는 것은 무리가 있으며, 시장 참여자는 세부적인 시장 특성별로 거래회전율 지표를 읽고 의사결정을 해야 할 것이다.

* 주저자, 한성대학교 일반대학원 부동산학과 박사과정, abcbogus@hansung.ac.kr

** 교신저자, 한성대학교 부동산학과 교수, ymlee@hansung.ac.kr

$※$ 본고의 내용은 필자의 개인 의견으로 한국주택금융공사의 공식적인 견해와 다를 수 있습니다. 


\section{I. 서론}

통상적으로 시장에서 거래되는 재화와 서비스의 가격과 거래량은 같은 방향으로 움직이는 속 성을 보인다. 부동산, 주택시장에서도 이러한 특징은 동일하게 관측되고, 세계 각국에서 동일하 게 목격되는 현상임에도 불구하고 그 원인에 대한 논의는 여전히 진행 중이다. 부동산의 거래량 과 가격이 같은 방향으로 움직인다는 것은 부동산 시장 참여자들에게 매우 중요한 정보가 된다. 예를 들어 가격과 거래량이 일관되게 같은 방향으로 움직이고, 시장참여자가 부동산 거래량 정 보를 사전에 알 수 있다면, 가격을 예측하기 용이해진다. 특히 부동산 시장의 가격 변동성이 크 고, 가격정보가 거래량 정보 보다 뒤늦게 공개되는 상황이라면 거래량 지표는 주택시장에 중요 한 정보로 활용될 수 있다1).

임대차시장에서도 거래량과 임대료 간의 관계를 알 수 있다면, 임대료 예측이 가능해 질 것이 다. 특히 전세의 경우, 주택 매매시장보다 변동성이 크고, 계약시점 목돈을 보증금으로 임대인 에게 제공해야 하며, 통상 2년 주기로 계약이 갱신되기 때문에 임차인에게 전세가격은 의사결 정에 중요한 변수로 작용한다. 따라서 전세시장에서도 거래량과 전세금 간의 관계에 대한 관심 은 클 수밖에 없다.

이처럼 부동산 시장에서 가격과 거래량 간 관계 규명의 필요성에도 불구하고, 국내에서는 부 동산, 주택시장에서 거래량과 가격에 관한 연구가 상대적으로 부진했다. 특히 전체 임차가구 점 유형태의 $40 \%$ 를 점하는 전세 시장은 분석에 필요한 거래량과 가격 정보 구득의 어려움으로 실 증분석이 전무한 실정이었다. 그 이유는 분석에 활용할 수 있는 정보 구득이 불가하다는 것이 가장 큰 원인이었다. 다행히 2005년 7월 제정된 「공인중개사의업무및부동산거래신고에관한법 률」에 의해 2006년 1월부터 거래된 실거래가격 정보가 축적되면서, 주택 매매가격과 거래량의 관계를 규명하고자 한 시도가 있었고, 한국에서도 주택 매매가격과 거래량 사이에 유의미한 정 (正)의 상관관계가 존재하는 결과가 허윤경(2008), 방송희(2010) 등에 의해 보고된 바 있다.

2011년 1월부터는 읍·면·동 주민센터를 통해 집계되던 확정일자 신고기반 전월세거래 정보 가 공개되기 시작했다. 그럼에도 불구하고 여전히 임대료와 거래량 간의 관계에 대한 연구는 거

1) 해외 선행연구에 따르면 대체적으로 자산 가격과 거래량 간에 정의 상관관계를 설명하는 이론으로 $\mathbf{0}$ 주택 구입 자금(down payment)의 변화는 구매력에 영향을 주기 때문에 주택가격 하락은 구매력을 하락시켜 거래량을 감 소시킨다(Stein, 1995)는 주택 구입자금 변화이론, (2전망이론(prospect theory)중 주택 소유자의 손실회피현상 (loss aversion)과 비대칭적 매도성향(disposition effect) 등 불확실성하에서의 의사결정이론(Genesove and Mayer, 2001; Engelhardt, 2003; Shefrin and Statman, 1985), 3정보이전효과 또는 정보의 비대칭성으로 인한 현상(Copeland, 1976; Jennings et. al., 1981; Smirlock and Starks, 1985) 등으로 설명하고 있다. 
의 없을 수밖에 없다. 공개되는 정보는 주택의 개별특성 및 단지특성과 거래특성 등 중요한 정 보가 누락되어 있고, 분석에 용이한 방식으로 제공되지 않다보니 활용 가능성이 낮으며, 특히 최근 빠르게 증가하고 있는 보증부월세의 경우, 보증금과 월세의 규모가 상호 대체되고 있어서 임대료의 정확한 수준을 알 수 없기 때문에 임대료와 거래량 간의 관계를 추정하기가 더욱 어 렵다.

전세제도는 사적인 금전대차와 주택임대차가 결합된 한국의 독특한 임대차제도로 알려져 있 다2). 전세의 현금흐름은 통상 매매가격의 50\% 80\% 수준의 많은 보증금을 입주시점에 임차인 이 임대인에게 선납하고, 전세계약이 종료되면 임대인은 계약시 수령한 보증금을 임차인에게 돌려줌으로써 계약이 종료된다.

과거 전후 주택의 양적 부족으로 도시의 주택난이 지속되는 상황에서 도시화, 산업화가 본격 화되면서 주택난은 정부가 해결해야 할 우선순위의 과제 중 하나였다. 반면, 당시 한국은 주택 금융의 미비로 제도권 금융을 이용할 수 없었기에, 주택 수요자와 공급자가 전세라는 형태의 사 적금융을 적극적으로 활용하면서 한국에서 전세제도는 보편적인 임대차 계약의 형태로 자리 잡 게 되었다.

\section{<그림 1> 가구의 주거점유형태 및 임차가구 중 전세 및 월세 비중}
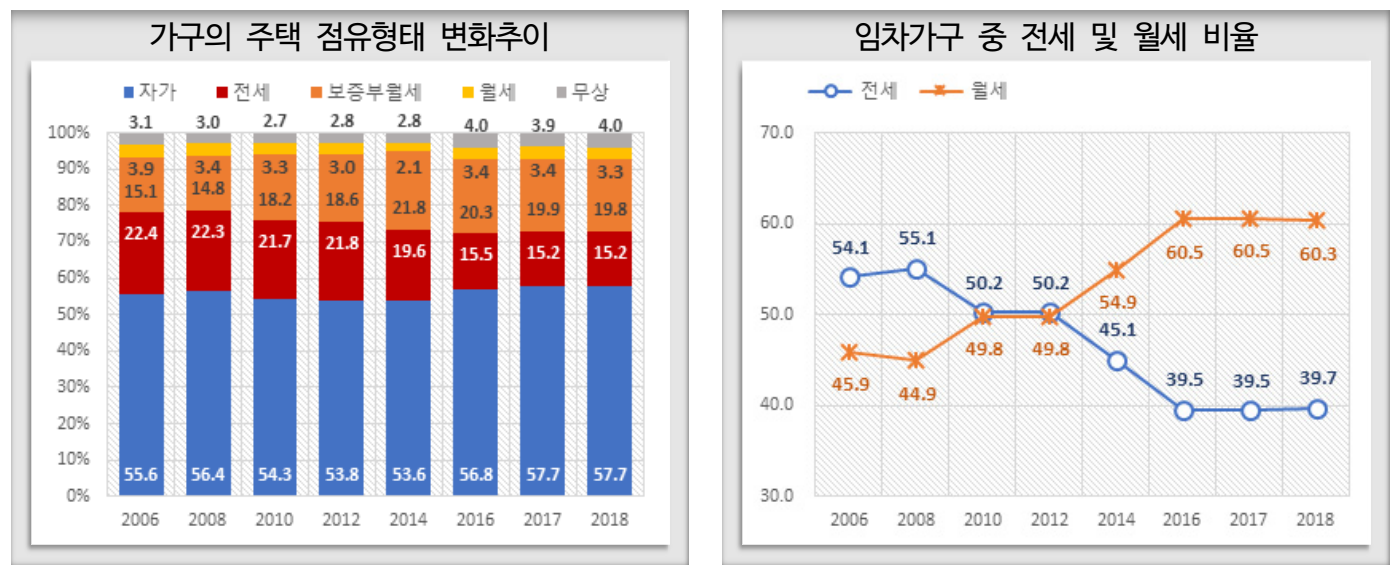

주) 보증금 없는 월세와 사글세는 월세로 집계, 임차가구는 무상 거주 가구와 자가 가구를 제외한 가구를 의미하며, 임차가구 중 월세는 보증부 월세가구를 포함.

자료 : 국토교통부, 주거실태조사 각 년도 자료로 재구성

2) 이용만, 2012, “전월세시장의 변환에 대한 이론적 분석과 정책적 시사점: 임차인 관점을 중심으로”, 글로벌 금융 위기 이후 주택정책의 새로운 패러다임 모색(하), KDI, 186-245 
주택금융 접근성 개선과 저금리 상황이 지속되면서 2000년 이후 전세가 전체 주택 임대차시 장에서 차지하는 비율은 빠른 속도로 낮아졌고, 이러한 현상을 두고, 인구구조의 변화, 세대별 주택 소비행태의 변화, 주택공급 환경의 변화 등을 이유로 궁극적으로 전세제도가 소멸될 것이 라는 전망이 지배적이었다. 그러나, 국토교통부에서 발표하는 주거실태조사 결과에 따르면 전 세는 2016년부터 임대차시장의 약 40\%의 점유율을 유지하면서, 여전히 한국에서 가장 일반적 인 주택 임대차 제도라 할 수 있고, 최근에는 금리 인하가 지속되는 상황에도 불구하고 오히려 임차 유형 중 전세 비중이 증가하고 있다.

본 연구는 전세시장을 대상으로 거래량과 임대료 간의 관계를 단지별로 분석해 보는 것이 목 적이다. 특히 거래량이 많은 단지의 전세가격이 비싼 것인지 여부를 확인하고자 한다. 전세시장 을 분석대상으로 삼은 이유는 보증부 월세시장의 경우 보증금과 월세 간의 대체 관계에 대한 사 회적 합의가 선행되어야 하는 상황에서 자료의 한계로 분석이 제한될 수밖에 없다. 제한된 정보 환경에서 상대적으로 분석의 편의성이 높은 전세시장을 분석대상으로 우선 선정하였다. 뿐만 아니라 전술한 바와 같이 전세는 목돈을 보증금으로 제공해야하기 때문에 거래량과 임대료 간 의 관계에 대한 관심이 클 수밖에 없다.

주택시장의 규모가 작고 대규모 단지형 중심으로 주택공급이 이루어지는 한국의 경우 주택 재고물량 대비 거래량을 의미하는 거래회전율이 거래량에 비해 더 많은 의미 있는 정보를 전달 하는 변수 일 수 있다. 이러한 문제는 이미 김현아·허윤경(2009)에 의해서도 제기된 바 있다. 특히, 최근 건축된 아파트의 경우 세대수 규모가 10,000 세대에 육박하는 등 초대형 단지가 공 급되고 있다. 반면, 단지 내 세대수 규모가 100세대에 못미치는 소규모 아파트 단지도 존재한 다. 아파트 단지가 품을 수 있는 세대의 규모가 큰 편차를 보이는 상황에서 동일하게 1 개월 동 안 1 천 건이 거래되었을 때 거래량이라는 절대적 수치는 공간에 대한 수요자의 선호, 상대적 거 래빈도 등과 같은 중요한 거래특성 정보를 잃게 된다.

이러한 문제의식에 기반하여 본 연구에서는 전세 실거래자료를 활용하여, 전세시장에서 가격 과 거래량의 관계를 규명하고자 한 시도로, 시세정보로 분석된 기존의 선행연구 분석결과, 전세 가격에 영향을 미치는 단지특성과 주택의 개별특성 이외에 거래의 특성이 반영된 거래회전율이 전세가격에 영향을 미치는지를 실증분석을 통해 확인하고자 한다. 


\section{II. 이론적 고찰 및 선행연구 검토}

\section{1. 확정일자 제도}

한국 주택시장에서 전세라는 사적금융 성격의 임대차계약이 보편적 유형으로 자리매김 함에 따라 정부는 주택임대차보호법을 통해 임차인의 보증금을 보호하기 위한 최소한의 조치를 마련 하였다. 그 중 하나가 확정일자제도이다. 이는 임대차 계약 시 임대인 또는 이해관계자의 채무 불이행으로 경매가 실행되더라도 주택임차인이 임차보증금에 대해 제3자에게 대항력을 행사하 여 후순위 담보물권자에 우선하여 보증금을 변제받을 수 있도록 한 제도이다. 이를 위해 임차인 은 임대차계약을 체결한 날짜에 대해 해당 동사무소나 법원(등기소)으로부터 확정일자인을 받 는다3).

반면, 확정일자 신고는 임차인의 의무가 아닌 선택사항이고, 우선변제를 받을 수 있는 임차인 의 보증금이 주택임대차보호법에서 정한 금액4)보다 적을 경우, 임차인은 확정일자 신고에 대한 실익이 없기 때문에 전세거래가 발생하더라도 신고의 유인이 없다. 따라서 매매거래 실거래 정 보와 달리 전세거래 계약이 발생하는 모든 건에 대해 확정일자 신고가 되지 않는다는 정보 수집 의 한계가 존재한다. 하지만, 서울 등 전세보증금 규모가 큰 지역에서는 확정일자 신고의 유인 이 높고, 확정일자 신고정보가 실제 임대차시장에서 발생하는 유일한 거래정보라는 의미를 고 려할 때 확정일자 신고정보는 그 한계에도 불구하고 전세 시장에서 가격과 거래량의 관계분석 을 위한 자료로 충분히 의미있는 분석 도구라고 할 수 있다.

\section{2. 전세거래 회전율과 전세가격}

전통적으로 한국의 임대차시장은 임대인 우위의 시장을 지속해왔다. 주택 총량에 비해 주택

3) 전입신고, 임차주택 점유의 요건을 갖추면 제3자에 대한 대항력을 가지며(주택임대차보호법 제3조제1항), 여기에 확정일자까지 갖추어야 보증금 최우선변제권이 발생한다(주택임대차보호법 제3조2제2항)

4) 주택임대차보호법 시행령 제 11 조에서 규정한 지역별 소액보증금의 범위와 최우선변제금액은 아래와 같다.

\begin{tabular}{c|c|c}
\hline 지역 & 소액보증금 범위 & 최우선변제금액 \\
\hline 서울시 & 11,000 만원 & 3,700 만원 \\
\hline 수도권 과밀억제권역 & 10,000 만원 & 3,400 만원 \\
\hline 광역시, 안산, 김포, 광주, 파주 & 6,000 만원 & 2,000 만원 \\
\hline 그 밖의 지역 & 5,000 만원 & 1,700 만원 \\
\hline
\end{tabular}


수요가 많고, 고가의 주택을 구입하기 위한 자산제약으로부터 자유로운 가구는 한정되므로 축 적된 자산이 부족한 가구에게 전세는 자가의 대체재로 활용되었다.

뿐만 아니라 상대적으로 월세에 비해 전세의 주거비용이 저렴하기 때문에 공간 수요자 입장 에서는 전세가 월세에 비해 우등재이므로 임대차 시장에서 전세 수요는 여전히 지속되고 있으 며 비탄력적이다. 반면, 만성적 초과수요 시장에서 가격결정권을 갖고 있는 임대인은 임대주택 에 대한 자기 자본 투입을 최소화하기 위해 전세보증금을 최대한 높게 책정하거나, 수익률과 현 금흐름을 고려하여 전세 또는 월세를 선택적으로 공급할 수 있다.

또 전세는 임차인이 목돈을 보증금으로 지불하고 점유하는 임대형태이기 때문에, 임차인이 해당 주택을 퇴거하고 다른 주택으로 이동하기 위해서는 보증금을 원하는 시기에 반환받을 수 있어야 한다. 특히 우리나라 전세 시장처럼 신규 임차인이 지불하는 보증금이 퇴거하는 임차인 의 보증금으로 반환되는 구조에서는 임차인이 원하는 시기에 퇴거할 수 있을 만큼 전세 거래가 활발한 단지가 선호될 것이며, 이는 거래소요 시간 지연 위험5)이 줄어든 만큼으로 해당 단지 전 세가격의 정(+)의 프리미엄으로 작용한다. 따라서 임차인은 전세거래 회전율이 높으면 퇴거가 용이한 만큼 기꺼이 거래 소요시간 지연 위험 할인 만큼을 더하여 전세가격을 지불할 수 있고, 임대인 또한 이러한 위험 할인 효과를 보다 나은 주거환경 요건으로 내세울 수 있을 것이다.

\section{<표 1> 전세 거래회전율과 전세가격의 관계}

\begin{tabular}{c|c|c}
\hline 구 분 & 전세가격이 높은 요인 & \multicolumn{1}{c}{ 전세가격이 낮은 요인 } \\
\hline $\begin{array}{c}\text { 거래 } \\
\begin{array}{c}\text { 회전율 } \\
\text { 증가 }\end{array}\end{array}$ & $\begin{array}{l}\text { ・임차수요 풍부 (임차인 선호) } \\
\text { 용이(거래 소요시간 지연 위험 할인) }\end{array}$ & $\begin{array}{l}\text { - 정보의 비대칭으로 인한 품질 낮은 주택의 } \\
\text { 거래가 빈번하게 발생 } \\
\text { 거래회전율을 통해 품질이 낮은 주택이라는 } \\
\text { 정보 유통 }\end{array}$ \\
\hline
\end{tabular}

한편, 주택은 개별성과 이질성이 크기 때문에 주택 시장에서 수요자, 특히 임차인은 정보의 비대칭적인 상황에 놓여있을 확률이 높다. 즉, 임대인은 임대하고자 하는 주택의 품질을 알지 만, 임차인은 입주하여 살기 전까지는 자신이 임차하고자 하는 주택의 품질이 낮은지 높은지를 알지 못한다. 설령 임차하여 입주한 주택의 품질이 낮더라도 다른 주택으로 이전하고자 하는 임 차인은 빠른 퇴거를 위해 그 주택의 품질을 시장에 알리지 않는다. 즉, 주택의 낮은 품질은 감추 어진 특성(hidden characteristic)이 되어 시장에서는 비대칭정보 상황이 조성되고, 품질 낮

5) 우리나라 전세거래시장에서 구 임차인과 신규 임차인 간의 퇴거/입주 날짜를 확정하는 것은 전세보증금 반환/지 급과 연동되어 있어 매우 중요한 거래 성립 요건이다. 따라서 전세 거래시 거래당사자들은 전세거래 소요시간 위험을 줄이기 위해 노력한다 
은 주택일수록 정보의 비대칭으로 인한 거래가 빈번하게 발생할 것이다. 이러한 이유에서 시장 에서는 거래회전율이 높은 단지가 상대적으로 전세가격이 낮을 수 있다.

더 나아가 품질이 상대적으로 낮은 주택에서는 임차인이 오랫동안 거주할 확률이 적어지고 이는 또다시 잦은 거래로 이어지는 결과, 활발한 거래를 통해 품질이 낮은 주택이라는 정보가 시장에 유통되면서 해당 주택의 전세 가격을 낮추는 요인으로 작용할 것이다.

전세거래의 활성화 정도를 살펴보기 위한 지표로서 전세 거래량이 있을 수 있다. 그러나 단순 히 거래량만을 비교할 경우, 단지별 세대수 크기에 따른 거래량 차이를 거래 활성화(혹은 거래 위축)로 과대(과소)추정하게 된다. 예를 들어 동일 지역일지라도 총 1,000 세대인 단지에서 전 세거래가 20건이 발생한 경우와 총 500세대인 단지에서 전세거래가 20건이 발생한 경우 이를 똑같은 거래활성화 정도로 판단해서는 안 될 것이다. 또 우리나라와 같이 대규모 아파트 단지 중심으로 신축(입주)되고 멸실되는 주택 시장에서는 신규 입주 및 멸실에 따라 거래량 수치가 민감하게 바뀔 수 밖에 없고 이를 고려하지 않을 때에는 거래량을 과대(과소) 추정하는 경우가 발생할 수 있다. 따라서 단지별 거래 활성화 정도는 주택재고량6) 대비 거래량 수준인 단지별 전 세거래 회전율로 살펴봄이 적절할 것이다.

이때 단지별 전세거래 회전율은 해당 단지의 세대수(단지의 주택 재고량) 대비 전세 거래량으 로 나타낼 수 있으며, 이 회전율이 높을수록 해당 단지의 전세 거래가 활발하고, 전세 수요가 상 대적으로 많음을 의미한다.

\section{3. 선행연구 검토}

전세와 매매를 포함한 주택가격에 영향을 미치는 요인들에 대한 검토는 2000년부터 다양하게 시도되었다. 그러나 상당수의 선행연구가 부동산가격정보업체의 시세자료를 활용하여 전세가격 결정요인을 분석하거나, 매매가격과 거래량의 관계를 분석하는 것에 그쳤다. 특히, 전세시장에 대 하여 실거래정보를 이용하여 회전율과 가격간의 관계를 조명한 연구는 전무하다 할 수 있다.

6) 단지의 전세거래 회전율을 정확히 산정하기 위해서는 단지 전체 세대수(재고 주택수) 보다 해당 단지내 전세 임대 중인 주택수 대비 전세 거래된 세대수(확정일자 신고된 세대수)를 사용하는 것이 바람직 할 것이다. 하지만 전세 세대수 자료 구득의 한계를 차제에 두더라도 근본적으로 자가로 이용되거나 다른 형태의 임대로 이용 중인 주택은 언제든지 전세로 점유형태가 전환될 수 있는 대체관계이고, 이러한 이유로 실제 전세 임대 주택수는 빈 번하게 변화하는 점을 고려할 때 전세거래 회전율 산정시 전체 세대수(재고 주택수)를 활용하는 데 무리가 없다 고 판단하였다. 
주택의 매매거래량과 가격 간에 상관관계를 밝힌 연구로는 허윤경 외(2008), 방송희(2010), 임재만(2011), 정홍일 외(2012), 김대원·유정석(2013), 김지혜(2017) 등이 있다.

허윤경 외(2008)은 가격과 거래량을 조명한 초기 연구로 가격이 변하면 거래량을 변화시킬 수 있음을 분석하였고, 방송희(2010)는 거래량이 가격에 선행하는 것으로 서로 다른 결과를 제 시하였다. 반면 임재만(2011)은 주택가격과 거래량은 상호 인과관계가 있으나, 가격이든 거래 량이든 상승시에는 상호 정(+)의 선후관계가 있지만 하락시에는 선후관계가 일관되지 않는 등 의 가격 상승기와 하락기 비대칭성이 존재함을 보고한 바 있다.

한편 가격과 거래량을 수익률의 관점에서 해석한 연구도 있었는데, 정홍일 외(2012)는 거래 량과 가격의 동조화 현상을 거시경제변수로 설명하면서 가격이 하락할 때 손실을 방지하기 위 해 거래를 줄이는 주택시장에서의 손실회피효과를 검증하였고, 김지혜(2017)는 아파트 규모에 따라, 특히 소형주택에서 거래량이 주택가격 수익률 변동성에 영향을 미침을 증명하였다.

또, 김대원·유정석(2013)은 패널데이터를 사용하여 주택가격에 대한 심리적 태도가 거래량 에 (+)의 영향을 주고 있음을 보여주며, 소비자심리지수가 주택시장에 중요한 변수임을 보여주 었다.

이들 연구는 주택가격과 거래량간 정(+)의 상관관계에 대한 결론은 일치하고 있지만, 선후관 계 또는 인과관계에 대해서는 의견을 달리하고 있으며, 지역별 시장상황의 상이함, 시장 참여자 들의 심리적 태도 또는 기대가치의 차이 등을 그 원인으로 설명하고 있다.

김현아·허윤경(2009)은 주택가격과 거래량이 일정한 영향 관계를 유지하고 있으며, 그럼에도 불구하고 우리나라와 같이 대규모 단지형 주택공급이 이루어지는 특수성을 고려하여 거래에 대 한 정보는 주택 재고 물량대비 거래량으로 정의한 회전율의 활용이 효과적이라고 강조하였다.

이외에 전세가격 결정요인에 대한 분석은 상대적으로 다수의 선행연구가 보고된 바 있다. 이 석주, 이주형(2011)은 전세가격 결정요인을 서울 4개 권역별로 구분하여 개별 단지 특성 변수 외에 각 권역별 지역 특성변수를 포함하여 분석을 시도하였다. 그 결과 각 권역별로 지역의 특성 이 전세가격 결정에 영향을 미치고, 그 요인이 각 권역별로 상이함을 규명하고자 시도하였다. 그 러나 권역과 관계없이 공통적인 전세가격은 지역경제, 단지규모, 문화생태환경, 편의성, 건설사 의 지명도, 물리사회적 환경, 주택보급률, 단지밀도에 의해 결정된다는 결론을 도출한 바 있다.

금상수, 한광호, 김행종(2014)은 천안시 아파트를 대상으로 전세가격 결정요인을 헤도닉모 형으로 분석하였는데, 물리적 특성은 전용면적, 경과연수, 현관구조, 난방방식 순으로 영향을 
미치며, 입지적 특성은 행정구역, 터미널까지의 거리, KTX역사까지의 거리, 중학교까지의 거 리 등이 영향을 미치는 것으로 나타났다. 그러나 이들의 연구는 분석에 활용한 자료의 출처가 불분명하다는 점에서 분석결과의 객관성을 확보하기에 한계가 있다.

김선주, 권기욱(2014)은 국토교통부에서 공공데이터로 제공하는 자료를 활용하여 전세가격 결정요인을 분석하였다. 주택 실거래 정보와 공동주택관리정보 중 공용관리비와 공용전기료, 그리고 아파트 단지정보를 활용하여 아파트의 물리적 특성과 단지의 단지특성, 관리비용 특성 으로 나누어 서울시 강남3구에 대한 전세가격 결정 요인을 분석하였다. 그 결과 경과년수, 승강 기대수, 난방방식 등은 전세가격에 유의미한 영향을 미치고, 단지의 관리비용적 특성은 유의하 지 않다는 결과를 보고 하였다7). 김선주, 권기욱(2014)의 연구는 실제 거래된 전세거래정보를 활용하였다는 점에서 기존의 선행연구에 비해 진일보 하였다 할 수 있으나 공공데이타에서 제 공하는 한정된 특성정보를 활용함에 따라 데이터 가용범위가 제한적이라는 한계를 갖고 있다.

주택가격과 회전율의 관계에 대한 분석결과의 부재에도 불구하고 김태경(2009)은 가격과 회 전율 간의 상관관계를 가정하고, 이것이 주택소유 행태에 미치는 영향을 규명하고자 시도하였 다. 김태경(2009)은 주택 매입과 매각 시점의 차이를 CPHM(Cox's proportional hazards model)모형의 확률로 치환하고 이를 소유회전율로 해석하면서 소유자와 거주자가 같은 그룹 과 소유자와 거주자가 다른 각각 그룹별로 소유회전율 크기에 영향을 미치는 요인을 분석하였 다. 그 결과 단위면적당 매입가격은 소유회전율에 영향을 미치고 있으며 이는 매입시점의 소유 주 연령에 따라서도 영향이 다름을 보여주었다.

지금까지 살펴본 바와 같이 전세시장에 대한 연구는 대체적으로 부동산 정보업체에서 제공된 시세정보나 공공데이타를 활용하여 단지나 개별주택의 물리적 특성이 전세가격 결정요인임을 규명하거나 또는 매매가격과 매매거래량사이에 통계적으로 유의적인 상관관계가 있음을 증명 해 보이는 연구가 대부분이었다.

본 연구는 선행연구를 확장하여 물리적 특성 외에 전세거래 회전율과 같은 임대차거래 특성 또한 임대차 가격의 결정요인이 될 수 있다는 가정을 실제 전세시장에서 거래된 전세확정일자 정보를 이용하여 실증분석 시도했다는 점에서 기존의 선행연구와의 차별성을 갖는다.

7) 저자는 관리비용적 특성도 유의하다고 기술하고 있으나, 분석 통계량을 $95 \%$ 유의수준에서 해석하면 유의하지 않은 것으로 판단된다. 


\section{III. 분석 모형 및 자료}

\section{1. 자료 및 변수}

전세거래 회전율과 같은 거래 특성에 따른 전세 가격을 확인하기 위해 본 연구는 주택가격 추 정 연구에서 주로 이용된 헤도닉가격모형을 사용하였다. 모형추정에 사용된 자료는 2018년 1 년 동안 서울 강남구와 노원구에서 전세계약이 체결된 아파트 전세확정일자 자료이다. 분석대 상 지역을 강남구와 노원구로 한정한 이유는 서울의 주택시장이 강남지역과 강북지역 간 차별 성이 존재하고, 각 지역이 서울의 강남지역과 강북지역을 대표하는 지역이자 서울 25 개 구 중 에서 아파트 재고량이 가장 많은 지역으로 거래자료를 풍부하게 확보할 수 있기 때문이다. 분석 대상 주택유형을 아파트로 한정한 것은 전세거래가 아파트 유형에서 상대적으로 높게 나타나 고, 전세보증금 규모가 크기 때문에 확정일자 신고 유인이 높으며, 개별 특성의 영향을 효과적 으로 통제하면서 거래회전율과 같은 거래특성의 영향을 정확히 관찰할 수 있기 때문이다.

확정일자 자료는 거래된 아파트의 계약일, 소재지, 면적, 거래금액 등을 포함하고 있으나 공 개된 이들 특성 변수만으로는 선행연구에서 일반적으로 검토된 헤도닉가격모형 추정이 불가하 다. 앞서 살펴본 바와 같이 전세가격을 결정하는 요인은 매우 다양하기 때문이다. 또 헤도닉가 격모형에서 변수누락(omitted variables) 문제가 발생하면 추정 결과에 편의(bias)가 생길 수 있다. 따라서 선행연구에서 검토된 전세 헤도닉가격모형에서 활용된 변수를 최대한 반영하고자 단지특성정보와 주택의 개별특성 정보를 연결하여 분석데이터를 구축했다.

주택의 경과년수, 재건축 대상여부, 세대수, 난방방식, 초등학교와의 거리, 지하철역과의 거 리와 같은 단지특성 정보는 한국감정원의 시세정보 사이트인 부동산 테크에서 구득하였고, 층, 아파트공시가격 정보는 국토교통부의 공개정보를 연결하였다. 재건축 대상여부는 경과년수가 30 년을 초과할 경우 일괄적으로 재건축 대상인 단지로 가정하여 모형에 반영하였고, 난방방식 은 중앙난방, 개별난방, 지역난방 각각의 경우에 대해 더미로 처리하였다. 마지막으로 본 연구 의 초점인 전세거래 회전율은 해당 단지의 세대수 대비 2018년 해당단지 전세거래 확정일자 신고건수를 계산하여 활용하였다.

반면, 아파트 공시가격에는 해당 단지의 세대수, 경과연수, 난방방식, 각종 편의시설과의 거 리와 같은 단지특성과 개별 주택 특성정보가 반영된 매매가격이므로 상기 전세가격 영향요인으 
로 거론한 특성정보와의 다중공선성 가능성을 고려하여〈모형 1〉은 아파트공시가격을 제외하 고 특성변수와 거래회전율을 독립변수로 설정하여 전세가격과의 관계를 살펴보았고, 〈모형 2〉 는 아파트 공시가격과 재건축 대상여부, 거래회전율을 독립변수로 구성하였다.

<표 2> 변수 특성과 자료의 형태

\begin{tabular}{|c|c|c|c|}
\hline 구분 & 변수명 & 내용 & 형태 \\
\hline 종속변수 & Deposit & 신고 전세금(백만원) & numeric \\
\hline \multirow{6}{*}{ 단지특성 } & apt_age & 아파트 경과년수 & numeric \\
\hline & rebuild & 재건축 대상 여부 & dummy \\
\hline & CNT & 단지세대수 & numeric \\
\hline & heat_num & $\begin{array}{l}\text { heat_1 : 중앙난방 } \\
\text { heat_2 : 개별난방 } \\
\text { heat_3 : 지역난방 }\end{array}$ & dummy \\
\hline & sch_dist & 가장 가까운 초등학교와의 거리 $(\mathrm{km})$ & numeric \\
\hline & stat_dist & 가장 가까운 지하철역과의 거리 $(\mathrm{km})$ & numeric \\
\hline \multirow{3}{*}{ 주택 특성 } & floor & 층 & numeric \\
\hline & AREA & 전용면적 $\left(m^{2}\right)$ & numeric \\
\hline & notice & 공시가격(백만원) & numeric \\
\hline 계약 특성 & occu_ratio & 연간 전세거래 회전율 & numeric \\
\hline
\end{tabular}

\section{2. 기초통계}

2018년 신고 된 아파트 전세확정일자자료 중 각 주택특성의 결측치를 제외하고 분석에 활용 된 자료는 강남구 195 개단지 7,586 건, 노원구 195 개단지 6,958 건이다. 단지별 전세거래회전 율을 살펴보면 강남구는 평균 $9.47 \%$, 노원구는 $6.09 \%$ 로 노원구보다는 강남구내 단지의 회전 율이 높았고, 단지회전율의 표준편차 또한 강남구(3.04\%)가 노원구(1.78\%)보다 큰 것으로 나 타났다. 이는 단지별 선호도의 분포가 강남구에서 더 넓게 나타나는 것으로 해석할 수 있다.

\section{<표 3> 분석대상 지역의 전세거래회전율 분포}

\begin{tabular}{c|c|c|c|c|c|c|c|}
\hline \multicolumn{9}{|c}{ 강남구 } & \multicolumn{5}{c}{ 노원구 } \\
\hline 평균 & 표준편차 & 최소값 & 최대값 & 평균 & 표준편차 & 최소값 & 최대값 \\
\hline $9.47 \%$ & $3.04 \%$ & $0.73 \%$ & $18.02 \%$ & $6.09 \%$ & $1.79 \%$ & $0.70 \%$ & $11.80 \%$ \\
\hline
\end{tabular}


〈표 4〉는 강남구와 노원구의 각 주택특성 변수별 분포를 보여주고 있다. 강남구의 신고 전세 가격은 1 억 이하부터 9억 초과 까지 다양하게 분포하고 그 중 5억 초과 9억 이하의 신고 건 비 중이 가장 높았다. 반면 노원구에서는 9억 초과 주택은 한 건도 없었고, 1 억 초과 3억 이하의 주택 신고 건이 전체의 $73.5 \%$ 를 차지하여 전세가격의 분포에서부터 큰 차이를 보였다. 두 지역 의 가격분포 차이는 신고주택의 면적특성과도 관련되어 있는 것으로 보인다. 강남구는 전용면 적이 $85 \mathrm{~m}^{2}$ 를 초과하는 주택이 전체 신고 건의 $65 \%$ 이상인 반면, 노원구는 전체 신고 건 중 전 용면적 $60 \mathrm{~m}^{2}$ 이하의 소형 아파트 비중이 $65.7 \%$ 로 높게 나타났다. 경과년수 또한 두 지역에서 차이를 보였다. 강남구의 아파트 단지 경과년수는 10 년 이하 부터 30 년 초과 까지 다양한 분포 를 보이는 반면, 노원구는 경과년수 10 년 이하의 신규단지 거래건이 관측되지 않았다. 다시 말 해 노원구 아파트 전세시장은 강남구보다 상대적으로 오래된 단지와 전용면적이 작은 소형이 주를 이루고 있음을 알 수 있다.

\section{<표 4> 변수별 분포}

\begin{tabular}{|c|c|c|c|c|c|c|}
\hline \multirow{2}{*}{\multicolumn{2}{|c|}{ 변수 }} & \multirow{2}{*}{ 분류 } & \multicolumn{2}{|c|}{ 강남 } & \multicolumn{2}{|c|}{ 노원 } \\
\hline & & & 빈도수 & $\%$ & 빈도수 & $\%$ \\
\hline \multirow{5}{*}{$\begin{array}{l}\text { 종속 } \\
\text { 변수 }\end{array}$} & \multirow{5}{*}{ 전세금 } & 9억초과 & 1,545 & $20.4 \%$ & 0 & $0.0 \%$ \\
\hline & & 5억초과 9억이하 & 3,270 & $43.1 \%$ & 194 & $2.8 \%$ \\
\hline & & 3억초과 5억이하 & 1,936 & $25.5 \%$ & 1,486 & $21.4 \%$ \\
\hline & & 1억초과 3억이하 & 58 & $0.8 \%$ & 5,112 & $73.5 \%$ \\
\hline & & 1억이하 & 58 & $0.8 \%$ & 166 & $2.4 \%$ \\
\hline \multirow{12}{*}{$\begin{array}{l}\text { 단지 } \\
\text { 특성 }\end{array}$} & \multirow{4}{*}{$\begin{array}{l}\text { 아파트 } \\
\text { 경과년수 }\end{array}$} & 10년이하 & 935 & $12.3 \%$ & & $0.0 \%$ \\
\hline & & 10년초과 20년이하 & 1,886 & $24.9 \%$ & 1,258 & $18.1 \%$ \\
\hline & & 20년초과 30년이하 & 1,865 & $24.6 \%$ & 2,827 & $40.6 \%$ \\
\hline & & 30년초과 & 2,900 & $38.2 \%$ & 2,873 & $41.3 \%$ \\
\hline & \multirow{4}{*}{ 단지 규모 } & 100세대 이하 & 11 & $0.1 \%$ & 1 & $0.0 \%$ \\
\hline & & 100세대 초과 300세대 이하 & 1,180 & $15.6 \%$ & 575 & $8.3 \%$ \\
\hline & & 300세대 초과 500세대 이하 & 1,320 & $17.4 \%$ & 798 & $11.5 \%$ \\
\hline & & 500세대 초과 & 5,075 & $66.9 \%$ & 5,584 & $80.3 \%$ \\
\hline & \multirow{4}{*}{$\begin{array}{c}\text { 학교와의 } \\
\text { 거리 }\end{array}$} & 100m 이하 & 228 & $3.0 \%$ & 250 & $3.6 \%$ \\
\hline & & $100 \mathrm{~m}$ 초과 $300 \mathrm{~m}$ 이하 & 2,403 & $31.7 \%$ & 4,393 & $63.1 \%$ \\
\hline & & $300 \mathrm{~m}$ 초과 $500 \mathrm{~m}$ 이하 & 3,037 & $40.0 \%$ & 1,771 & $25.5 \%$ \\
\hline & & 500m 초과 & 1,918 & $25.3 \%$ & 544 & $7.8 \%$ \\
\hline
\end{tabular}




\begin{tabular}{|c|c|c|c|c|c|c|}
\hline \multirow{2}{*}{\multicolumn{2}{|c|}{ 변수 }} & \multirow{2}{*}{ 분류 } & \multicolumn{2}{|c|}{ 강남 } & \multicolumn{2}{|c|}{ 노원 } \\
\hline & & & 빈도수 & $\%$ & 빈도수 & $\%$ \\
\hline \multirow{7}{*}{$\begin{array}{l}\text { 단지 } \\
\text { 특성 }\end{array}$} & \multirow{4}{*}{$\begin{array}{c}\text { 지하철역 } \\
\text { 거리 }\end{array}$} & $100 \mathrm{~m}$ 이하 & 72 & $0.9 \%$ & 106 & $1.5 \%$ \\
\hline & & $100 \mathrm{~m}$ 초과 $300 \mathrm{~m}$ 이하 & 1,483 & $19.5 \%$ & 1,117 & $16.1 \%$ \\
\hline & & $300 \mathrm{~m}$ 초과 $500 \mathrm{~m}$ 이하 & 2,358 & $31.1 \%$ & 2,321 & $33.4 \%$ \\
\hline & & $500 m$ 초과 & 3,673 & $48.4 \%$ & 3,414 & $49.1 \%$ \\
\hline & & 중앙난방 & 3,879 & $51.1 \%$ & 1,513 & $21.7 \%$ \\
\hline & & 개별난방 & 1,978 & $26.1 \%$ & 1,139 & $16.4 \%$ \\
\hline & & 지역난방 & 1,729 & $22.8 \%$ & 4,306 & $61.9 \%$ \\
\hline \multirow{8}{*}{$\begin{array}{l}\text { 개별 } \\
\text { 주택 } \\
\text { 특성 }\end{array}$} & \multirow{4}{*}{$\begin{array}{l}\text { 아파트 } \\
\text { 층수 }\end{array}$} & 5층 이하 & 2,776 & $36.6 \%$ & 2,574 & $37.0 \%$ \\
\hline & & 5층 초과 10층 이하 & 2,426 & $32.0 \%$ & 2,168 & $31.2 \%$ \\
\hline & & 10층 초과 15층 이하 & 1,751 & $23.1 \%$ & 1,939 & $27.9 \%$ \\
\hline & & 15층 초과 & 633 & $8.3 \%$ & 277 & $4.0 \%$ \\
\hline & \multirow{4}{*}{$\begin{array}{l}\text { 전용 } \\
\text { 면적 }\end{array}$} & $60 \mathrm{~m}^{2}$ 이하 & 2,193 & $28.9 \%$ & 4,574 & $65.7 \%$ \\
\hline & & $60 \mathrm{~m}^{2}$ 초과 $85 \mathrm{~m}^{2}$ 이하 & 435 & $5.7 \%$ & 1,857 & $26.7 \%$ \\
\hline & & $85 \mathrm{~m}^{2}$ 초과 $105 \mathrm{~m}^{2}$ 이하 & 1,935 & $25.5 \%$ & 150 & $2.2 \%$ \\
\hline & & $105 m^{2}$ 초과 & 3,023 & $39.8 \%$ & 377 & $5.4 \%$ \\
\hline \multirow{5}{*}{\multicolumn{2}{|c|}{ 공시가격 }} & 1억이하 & 0 & $0.0 \%$ & 5 & $0.1 \%$ \\
\hline & & 1억초과 3억이하 & 165 & $2.2 \%$ & 5,683 & $81.7 \%$ \\
\hline & & 3억초과 5억이하 & 769 & $10.1 \%$ & 1,229 & $17.7 \%$ \\
\hline & & 5억초과 9억이하 & 2,572 & $33.9 \%$ & 41 & $0.6 \%$ \\
\hline & & 9억초과 & 4,080 & $53.8 \%$ & 0 & $0.0 \%$ \\
\hline \multicolumn{3}{|r|}{ 총합계 } & 7,586 & $100.0 \%$ & 6,958 & $100.0 \%$ \\
\hline
\end{tabular}

본 연구에서는 전세 거래회전율이 높으면 전세시장 가격이 높을 것이라는 전제를 하고 있다. 그렇다면 수집된 데이터에서 거래회전율이 높은 단지들의 특징을 살펴볼 필요가 있을 것이다. 왜냐하면 거래회전율이 높은 단지들이 공교롭게도 전세가격이 높게 형성될 요소를 지니고 있을 수도 있기 때문이다. 만일 그러하다면 강남구와 노원구의 거래회전율이 높은 단지의 특성은 두 지역 모두 유사하게 나타날 것이다.

〈표 5〉는 강남구와 노원구의 거래회전율 상위 3개 단지의 특징을 요약한 것이다. 2018년 강 남구에서 전세거래 회전율이 높은 단지는 경과년수가 20년초과 30년이하이고, 세대수는 300 세대 이하인 소단지이거나 500세대 초과인 대단지이며 초등학교와는 $500 \mathrm{~m}$ 초과이나 $1 \mathrm{~km}$ 이 내인 단지였다. 반면 노원구의 거래 회전율이 높은 단지는 경과년수가 20 년을 초과하고 세대수 는 100 세대 초과이나 500세대 이하인 중소규모이고, 초등학교와는 $100 \mathrm{~m}$ 초과이나 $1 \mathrm{~km}$ 이내 
인 단지로서 강남구의 회전율이 높은 단지와 그 성격이 다르게 나타났다.

<표 5> 지역별 거래회전율 상위 단지의 특성

\begin{tabular}{|c|c|c|}
\hline 특성 & 강남구 & 노원구 \\
\hline 거래회전율 & $\geq 15.0 \%$ & $\geq 10.8 \%$ \\
\hline 아파트 경과년수 & 20년 초과 30년 이하 & 20년 초과 \\
\hline 단지세대수 & $\begin{array}{c}\text { 300세대이하 } \\
\text { 또는 500세대 초과 }\end{array}$ & 100세대초과 500세대 이하 \\
\hline 난방방식 & 중앙, 개별, 지역난방 & 중앙, 지역난방 \\
\hline 가장 가까운 초등학교와의 거리 $(\mathrm{km})$ & $500 \mathrm{~m}$ 초과 $1 \mathrm{Km}$ 이내 & $100 \mathrm{~m}$ 초과 $500 \mathrm{~m}$ 이내 \\
\hline 가장 가까운 지하철역과의 거리 $(\mathrm{km})$ & $100 \mathrm{~m}$ 초과 & $100 \mathrm{~m}$ 초과 \\
\hline
\end{tabular}

\section{$\mathrm{IV}$. 분석결과}

수집된 전세확정일자 자료는 2018년 내 각 시기별로 신고 된 자료이므로, 헤도닉가격모형으 로 추정하기 위해서는 일정 시점가격으로 신고 된 전세가격을 보정해줄 필요가 있다. 이에 수집 된 전세가격 자료는 전국주택가격동향조사 월간 아파트 가격지수를 적용하여 2018.1월 기준 전세 가격으로 보정한 뒤, 전용면적 기준 단위면적당 로그 전세가격으로 헤도닉모형을 구축하 였다. 관측 가능한 단지 특성과 개별 주택특성을 모두 포함한 일반 헤도닉가격모형(모형 1)의 변수 추정결과는 〈표 6〉과 같다.

\section{<표 6> 헤도닉가격모형 분석 결과(모형 1)}

\begin{tabular}{l|c|c|c|c|c|c|}
\hline \multicolumn{1}{|c|}{ 구분 } & \multicolumn{3}{|c}{ 강남(adj R_sq=0.2135) } & \multicolumn{3}{c}{ 노원(adj R_sq=0.3732) } \\
\hline Variable & $\begin{array}{c}\text { Parameter } \\
\text { Estimate }\end{array}$ & $\begin{array}{c}\text { Standard } \\
\text { Error }\end{array}$ & t Value & $\begin{array}{c}\text { Parameter } \\
\text { Estimate }\end{array}$ & $\begin{array}{c}\text { Standard } \\
\text { Error }\end{array}$ & t Value \\
\hline Intercept & $16.33259 * *$ & 0.03271 & 499.25 & $15.16823 * * *$ & 0.01657 & 915.42 \\
\hline apt_age & $-0.00622 * * *$ & 0.00085 & -7.29 & $-0.00578 * * *$ & 0.00049 & -11.63 \\
\hline rebuild & $-0.19025 * *$ & 0.01863 & -10.21 & $0.08288 * * *$ & 0.00536 & 15.47 \\
\hline
\end{tabular}




\begin{tabular}{l|c|c|c|c|c|c}
\hline \multicolumn{1}{c|}{ 구분 } & \multicolumn{3}{c}{ 강남(adj R_sq=0.2135) } & \multicolumn{3}{c}{ 노원(adj R_sq=0.3732) } \\
\hline \multirow{2}{*}{ Variable } & $\begin{array}{c}\text { Parameter } \\
\text { Estimate }\end{array}$ & $\begin{array}{c}\text { Standard } \\
\text { Error }\end{array}$ & t Value & $\begin{array}{c}\text { Parameter } \\
\text { Estimate }\end{array}$ & $\begin{array}{c}\text { Standard } \\
\text { Error }\end{array}$ & t Value \\
\hline CNT & $-0.00002 * * *$ & 0.00000 & -5.10 & $0.00001 * * *$ & 0.00000 & 7.70 \\
\hline heat_1 & $-0.02909 * *$ & 0.01159 & -2.51 & $-0.05778 * * *$ & 0.00442 & -13.08 \\
\hline heat_2 & $-0.05225 * * *$ & 0.01355 & -3.86 & $-0.00247 *$ & 0.00493 & -0.50 \\
\hline floor & $0.01035 * * *$ & 0.00072 & 14.31 & $0.00719 * * *$ & 0.00031 & 22.85 \\
\hline area & $-0.00029 *$ & 0.00015 & -1.93 & $-0.00115 * * *$ & 0.00008 & -13.96 \\
\hline sch_dist & $-0.36669 * *$ & 0.02550 & -14.38 & $-0.13025 * *$ & 0.01299 & -10.03 \\
\hline stat_dist & $-0.12503 * * *$ & 0.00701 & -17.83 & $-0.02619 * * *$ & 0.00342 & -7.66 \\
\hline occu_ratio & $-0.45009 * * *$ & 0.16810 & -2.68 & $2.77619 * * *$ & 0.09628 & 28.84 \\
\hline
\end{tabular}

주) *,**,** 표시는 각각 $10 \%, 5 \%, 1 \%$ 유의수준에서 통계적으로 유의미함을 의미

변수의 수치나 부호 모두 선행연구의 헤도닉가격모형 추정결과와 유사하여 본 연구에서 구축 된 자료가 전세가격을 분석하는데 적합함을 확인할 수 있다. 아파트 경과년수, 전용면적, 학교 와의 거리, 지하철역과의 거리는 단위면적당 전세가격에 통계적으로 유의미하게 음(-)의 영향 을 보였다. 그리고 개별 주택의 층수는 단위면적당 전세가격에 통계적으로 유의미한 양(+)의 영 향을 미치는 것으로 나타났다.

반면, 난방방식에 대한 해석에는 주의를 요한다. 강남구에서는 지역난방 대비 개별난방과 중 앙난방은 단위면적당 전세가격에 통계적으로 유의한 음의 영향을 미치고 있다. 하지만 노원구 에서는 지역난방대비 중앙난방이 단위면적당 전세가격에 통계적으로 유의한 음의 영향을 미치 는 것으로 나타났다. 개별난방은 통계적으로 유의하지 않게 나타났다. 이는 단위면적당 전세가 격에 미치는 영향이 지역난방과 유사하거나 또는 영향을 미치지 않는 것으로 해석할 수 있다.

재건축 대상여부 또한 강남구와 노원구에서 각기 다른 부호가 나타났고, 통계적으로 유의미 하게 설명되었다. 이는 강남구와 노원구의 재건축 활성정도(사업진척 속도)에 차이 때문일 수 있다. 즉, 재건축 대상이 되는 노후 아파트의 경우 재건축 사업에 대한 기대가치가 반영되면서 매매가격은 상승하는 반면, 노후한 공간 수요가 감소하면서 전세 가격이 하락한다. 이러한 특징 은 재건축 사업의 진척 속도에 따라 더 빠르게 진행될 것이다.

아파트 신축 이후 전세가격은 매매가격과 일정 비율을 유지하며 가격 수준을 형성하지만, 다 
른 외부 환경이 일정하다면 아파트가 노후화될수록 매매가격은 향후 개발이익 기대가치로 가격 수준을 유지하거나 오히려 상승하는 반면, 사용가치인 전세가격은 하락하게 된다. 이렇게 매매 가격과 전세가격 증감의 방향이 바뀐 이후에도 해당 단지가 재건축 사업을 시작하게 되면 매매 가격과 전세가격은 각각 달라진 증감의 방향에서 그 폭이 더욱 커진다. 즉, 매매가격은 짧은 미 래에 실현될 기대 이익이 즉각적으로 반영되어 가격 상승세가 더욱 커지는 반면, 해당 단지는 짧은 미래에 재건축되어 멸실 될 예정이므로 관리가 더욱 소홀해짐에 따라 주거환경은 더욱 열 악해지고 이는 곧 사용가치인 전세가격을 더욱 빠르게 하락시킨다.

이러한 점들을 고려해 볼 때, 위의 분석결과는 상대적으로 재건축 사업 진척 속도가 빠른 강 남에서는 재건축 대상 아파트가 전세 가격에 음의 영향을 주는 것으로 나타난 반면, 노원구는 재건축 대상 단지가 사업의 착수에 이르는데 상대적으로 불리한 조건을 갖고 있기 때문에 사업 진척이 있는 단지가 적어 가설과 다른 결과가 도출되었을 가능성을 배제할 수 없다.

본 연구의 주요 관심 대상인 전세거래회전율 또한 전세가격에 통계적으로 유의미한 영향을 미치는 것으로 나타났다. 그러나 부호는 강남구와 노원구에서 각각 달랐다. 강남구에서는 거래 회전율이 높을수록 전세가격에 유의한 음의 영향을, 노원구에는 양의 영향을 주는 것으로 나타 났다. 이는 강남구에서는 거래가 활발한 단지의 전세가격이 상대적으로 낮고, 노원구에서는 거 래가 활발한 단지의 전세가격이 높음을 의미한다.

\section{<표 7> 헤도닉가격모형 분석 결과(모형 2)}

\begin{tabular}{l|c|c|c|c|c|c}
\hline \multicolumn{1}{c|}{ 구분 } & \multicolumn{3}{c}{ 강남(adj R_sq=0.2133) } & \multicolumn{3}{c}{ 노원(adj R_sq=0.9815) } \\
\hline Variable & $\begin{array}{c}\text { Parameter } \\
\text { Estimate }\end{array}$ & $\begin{array}{c}\text { Standard } \\
\text { Error }\end{array}$ & t Value & $\begin{array}{c}\text { Parameter } \\
\text { Estimate }\end{array}$ & $\begin{array}{c}\text { Standard } \\
\text { Error }\end{array}$ & t Value \\
\hline Intercept & $15.55022 * * *$ & 0.02172 & 715.91 & $14.16944 * * *$ & 0.00173 & 8182.29 \\
\hline rebuild & $-0.39365 * * *$ & 0.00951 & -41.39 & $-0.00300 * * *$ & 0.00059 & -5.05 \\
\hline notice & $0.05077 * * *$ & 0.00164 & 30.99 & $0.25169 * * *$ & 0.00047 & 527.23 \\
\hline occu_ratio & $-1.60650 * * *$ & 0.14107 & -11.39 & $0.16932 * * *$ & 0.01671 & 10.13 \\
\hline
\end{tabular}

주) *,**,*** 표시는 각각 $10 \%, 5 \%, 1 \%$ 유의수준에서 통계적으로 유의미함을 의미

〈모형 1〉에서 수집 가능한 최대한의 단지 특성과 주택의 개별특성을 반영하였다고 하더라도 헤도닉가격모형에서 변수누락의 문제는 얼마든지 발생할 수 있다. 이에 주택가격 형성에 필요 한 모든 특성이 반영되었다 할 수 있는 주택 공시가격을 설명변수로 활용한 〈모형 2〉를 구축하 
였다.

일반적으로 전세가격은 매매가격으로 추정된 공시가격과 일정 비율 수준의 격차를 유지하는 경향을 보인다. 그러나 주택이 노후화되고 재건축 대상이 되면 매매가격과 전세가격의 방향이 반대방향으로 달라진다. 이는 재건축 대상이 된 주택은 주택 본연의 가치인 공간가치보다 자산 가치에 높은 가중치가 적용되기 때문이다. 즉, 재건축 대상단지의 공시가격은 자산가치가 높아 지면서 상승하지만 전세가격은 공간사용에 대한 대가이므로 노후로 인한 공간가치 하락으로 점 점 하락하는 경향을 보인다. 이에 〈모형 2〉는 전세와 자가가 대체재 관계에 있어 가격형성요인 이 동일하다고 가정하여 아파트 공시가격과 재건축 대상여부만으로 설명변수를 구성하였다.

〈모형 2〉 분석 결과, 노원구는 모형설명력이 98.1\%로 매우 높게 나타났고〈모형 1〉보다 설 명력이 개선된 것을 볼 수 있다. 이는 노원구의 전세가격은 공시가격과 일정비율의 격차를 두고 같은 방향으로 변화하는 특징과 매매가격(공시가격)과 전세가격의 결정요인이 유사하다는 가설 을 뒷받침하는 결과라 할 수 있다8).

반면 강남구의 전세가격은 노원구와 달리 공시가격으로 모형 설명력이 크게 개선되지 않았 다. 이는 강남구의 전세가격이 매매가격(공시가격) 결정요인 이외에 다른 변수로 설명되는 특수 한 시장일 가능성이 높아 보인다. 본 연구에서는 상기 의문에 대한 결론을 도출하지 못한 바, 향 후 강남구 전세시장의 특수성을 밝히는 실증분석을 검토할 필요가 있다.

〈모형 1〉에서 부호의 차이를 보였던 재건축 대상여부가 〈모형 2〉에서는 강남구와 노원구 모 든 지역에서 전세가격에 통계적으로 유의한 음의 영향을, 공시가격은 양의 영향을 주는 것으로 나타났다.

특히 노원구의 경우 〈모형 1)과 〈모형 2〉에서 재건축 대상여부 부호가 다르게 나타났는데, 모형 설명력이 개선된 〈모형 2〉에서 재건축 대상여부가 강남구와 같이 전세가격에 통계적으로 유의한 음의 영향을 보임으로써, 전술한 바와 같이 재건축 대상 단지의 전세가격이 상대적으로 낮음은 지역에 관계없이 일관된 시장 현상으로 판단된다.

반면, 전세거래회전율이 전세가격에 미치는 영향은 두 지역의 부호가 다르게 나타났다. 강남 구에서는 전세거래 회전율이 전세가격에 통계적으로 유의하게 음의 영향을, 노원구에서는 양의 영향을 주는 것으로 나타나 〈모형 1)과 차이를 보이지 않았다.

8) 2018 년 주택가격동향조사에서 노원구 아파트의 매매가대비 전세가 비율 평균은 $73.5 \%$ 로 공시가격 현실화율(실 거래가격대비 공시가격 수준) $68 \%$ 와 매우 유사한 수준이다. 


\section{V. 결론 및 정책적 시사점}

본 연구는 대단지 중심의 아파트 공급구조로 확대되는 한국 주택공급의 특징 변화를 고려하 여 주택거래정보의 왜곡을 최소화한 전세거래 회전율이 전세가격에 어떤 영향을 미치는지를 실 증분석 하고자 하였다.

분석결과〈모형 1〉과 〈모형 2〉에서 공통적으로 강남구는 전세거래 회전율이 높은 단지일수 록 전세가격은 낮고, 반대로 노원구는 전세거래 회전율이 높은 단지일수록 전세가격이 높은 일 관된 결과를 보여주고 있다. 이는 전세거래회전율이 전세시장의 지역적 차이와 특성에 따라 거 래가격과 미치는 영향이 다를 수 있다는 점을 시사한다.

그렇다면 강남구와 노원구의 전세시장은 어떤 특성 때문에 전세거래회전율 크기와 전세가격 방향이 다르게 나타나는 것일까? 그 원인에 대하여 추가적 분석 없이 단언할 수는 없지만 다음 과 같은 합리적 의심을 해 볼 수 있다.

강남구는 주택시장에 대한 소비자 선호도가 높은 지역인 반면에 지역내 주택 품질에 대한 정 보는 알 수 없다. 강남구는 특히 지역 선호도가 거래 의사결정에 더 큰 영향을 주는 지역이므로 주택 내부를 살펴보는 과정을 거치지 않고 주택 임대차 계약이 발생하기도 한다. 이렇게 주택 품질에 대한 정보 비대칭성이 큰 지역인 만큼 품질 낮은 주택 거래가 상대적으로 자주 일어날 수 있는 환경이며 이는 결과적으로 전세 거래가 활발한 단지는 전세 가격이 낮은 것으로 나타날 수 있다. 이 경우 높은 전세 거래 회전율은 역으로 품질이 낮은 주택이라는 정보로 인식되어 유 통됨으로써 전세 가격을 더욱 낮추는 효과를 부를 수 있다.

한편 노원구는 2018년 주택가격동향조사 아파트 전세가격지수가 연초 99.7 대비 연말 99.4 로 전세가격 변동성이 낮고, 전세가격이 안정된 지역이다. 이 곳에서 전세거래회전율이 큰 단지 는 임차인의 입주와 퇴거가 용이하여 전세 거래 지연 위험이 적어 상대적으로 높은 전세가격을 형성할 수 있을 것이다.

따라서 전세거래회전율이 높은 시장의 전세가격이 무조건 비싸다고 해석하기보다 지역별 주 택시장 컨디션과 시장참여자의 소요 차이에 따라 다른 결과가 도출될 수 있음을 간과해서는 안 될 것이다. 또한 이러한 특징은 매매시장에도 유사하게 적용될 것으로 보인다.

본 연구에서는 전세거래회전율이라는 거래특성에 따른 전세가격 수준을 실증분석하였다. 전 세거래회전율이 전세가격에 미치는 영향은 지역에 따라 다른 결과를 보였는 바, 주택시장 참여 
자가 합리적인 의사결정을 위해서는 시장의 세부 특성별로 거래회전율 검토 필요성을 실증분석 결과로 확인 하였다는 점에서 정책적 함의와 학술적 의의가 있다.

하지만 본 연구에서는 거래회전율이 세부시장별로 전세가격에 미치는 영향이 상이하게 나타 나는 이유를 규명하는 수준에까지는 미치지 못했다. 세부 시장별로 거래회전율이 가격에 미치 는 영향을 알 수 있다면 전세시장을 보다 풍부하게 이해하고 임대시장을 해석할 수 있을 것이 다.

본 연구를 기초로 임대 시장에서 정보의 비대칭성을 해소할 수 있는 다양한 연구와 노력이 시 도되고, 더 나아가 정부의 공신력있는 부동산 통계지표가 시장에 공급되어 주거 안정을 위한 세 부적이고 구체적인 임대차 정책 수립에도 일조할 수 있기를 기대해 본다.

\section{참교문헌}

김대원·유정석, 2013, “주택가격에 대한 심리적 태도가 주택 매매 거래량에 미치는 영향 분석”, 주택연 구, 21권 2호, 73-92.

김선주·권기욱, 2014, “공공데이터를 활용한 전세가격 결정요인, 서울시 강남지역 아파트를 중심으로", 한국지적정보학회지 16권 3호, 173-184

김지혜, 2017, “한국 주택시장에서 규모별 아파트 거래량이 비대칭 변동성에 미치는 영향”, 대한경영학회 지, 30권 11호, 1935-1952.

김태경, 2009, “주택의 소유유형에 따른 소유회전율 결정요인에 관한 연구”, 국토계획 44권 3호, 125-135 김현아·허윤경, 2009, “부동산 거래량 통계의 활용방안 연구”, 국토연구, 107-124

금상수·한광호 · 김행종, 2014, “천안시 아파트 전세가격 결정요인”, 주거환경 12권1호, 145-158 방송희, 2010, “주택 가격지수와 관련된 세가지 에세이”, 한성대학교 경제부동산학과 박사학위논문 이석주·이주형, 2011, “서울시 아파트 전세가격 결정요인의 권역별 특성에 관한 연구”, 한국생태환경건축 학회 논문집 11권 4호, 19-27

이용만, 2012, “전월세시장의 변환에 대한 이론적 분석과 정책적 시사점: 임차인 관점을 중심으로”, 글로벌 금융위기 이후 주택정책의 새로운 패러다임 모색(하), KDI, 186-245

임재만, 2011, “주택거래량은 주택가격 변동을 설명할 수 있는가?," 국토연구, 3-18.

정홍일·이현석·이상선, 2012, “주택 거래량과 가격의 동조화 및 손실회피현상”, 주택연구, 20권 2호, 77-101.

허윤경·장경석·김성진·김형민, 2008 , "주택 거래량과 가격 간의 그랜저 인과관계 분석 - 서울 아파트 시 장을 중심으로”, 주택연구 16권, 4호, 49-70.

Genesove, David \& Christopher Mayer, "Loss Aversion And Seller Behavior: Evidence From

The Housing Market," The Quarterly Journal of Economics, Vol.116 No.4, 2001, 
pp.1233-1260.

Jennings, R., Starks, L., Fellingham, J., "An Equilibrium Model of Asset trading with Sequential Information Arrival," Journal of Finance, Vol.36 No.1, 1981, pp.143-161. Kahneman, D., Knetsch, J. L., Thaler, R. H., "Anomalies: The Endowment Effect, Loss Aversion, and Status Quo Bias." Journal of Economic Perspectives, vol.5, no.1, 1991, pp.193-206.

Lakonishok J., S. Smidt, "Volume for winners and Losers: Rasation and Other Motives for Stock Trading," The Journal of Finance, vol.41, 1986, pp.951-974.

Smirlock, M, Starks, L., "A Further Examination of Stock Price Changes and Transaction Volume," Journal of Financial Research, Vol. 8, 1985, pp. 217-225.

Stein, Jeremy C, "Prices and Trading Volume in the Housing Market: A Model with DownPayment Effects," The Quarterly Journal of Economics, Vol.110 No.2, 1995, pp.379-406. 